\title{
Study of Changes in Corneal Thickness and Corneal Endothelial Cell Density after Phacoemulsification Cataract Surgery
}

\author{
Rajiv Pardasani ${ }^{1}$, Sohan Lohiya² \\ ${ }_{1,2}$ Department of Ophthalmology, Jawaharlal Nehru Medical College, Datta Meghe Institute of Medical \\ Sciences (Deemed to Be University), Sawangi (Meghe), Wardha, Maharashtra, India.
}

\section{ABSTRACT}

\section{BACKGROUND}

Phacoemulsification is a common surgery for cataract. The endothelium comprises of hexagonal cells which in single layer is essential for maintaining the transparency of the cornea. We wanted to compare endothelial cell density (ECD), central corneal thickness (CCT), coefficient of variability, and hexagonality of endothelial cells before and after phacoemulsification surgery. we also wanted to evaluate the endothelial cell loss after phacoemulsification surgery.

\section{METHODS}

A rural hospital-based prospective observational study with 120 patients was conducted in a hospital based setting utilising the data of patient's eye by considering inclusion and exclusion criteria, before and after phacoemulsification surgery by using noncontact specular microscope.

\section{RESULTS}

The mean endothelial cell density significantly decreased postoperatively at day one, $4^{\text {th }}$ week, $12^{\text {th }}$ week. The mean central corneal thickness increased significantly at postoperative day one, then subsequently decreased at postoperative $4^{\text {th }}$ week and $12^{\text {th }}$ week $(\mathrm{P}$ value $=0.0001)$, but never reached the preoperative value. There was a significant change in coefficient of variation and hexagonality postoperatively ( $P$ value $=0.0001$ )

\section{CONCLUSIONS}

The primary result is the change in corneal endothelial cell density (cells per square millimetre of the corneal surface) which is decreased, and the central corneal thickness calculated in micro meter is increased. As endothelial cells do not replicate, to reimburse cell loss there are changes in coefficient of variation and hexagonality after phacoemulsification surgery.

\section{KEY WORDS}

Corneal Endothelial Cell Density, Central Corneal Thickness, Coefficient of Variation, Hexagonality, Phacoemulsification, Specular Microscope
Corresponding Author: Dr. Rajiv Pardasani F 16 Raghobaji Boys Hostel, Datta Meghe Institute of Medical Sciences (Deemed to Be University), Sawangi (Meghe), Wardha Maharashtra, India. E-mail: rajeev.pardasani@gmail.com

DOI: $10.14260 / j e m d s / 2021 / 187$

How to Cite This Article:

Pardasani R, Lohiya S. Study of changes in corneal thickness and corneal endothelial cell density after phacoemulsification cataract surgery. J Evolution Med Dent Sci 2021;10(12):866-872, 10.14260/jemds/2021/187

Submission 02-11-2020,

Peer Review 26-01-2021,

Acceptance 02-02-2021, Published 22-03-2021.

Copyright (C) 2021 Rajiv Pardasani et al. This is an open access article distributed under Creative Commons Attribution License [Attribution 4.0 International (CC BY 4.0)] 


\section{BACKGROUND}

Visual impairment (VI) being a health problem is associated with augmented morbidity. In India approximately 62 million have visual impairment; in which 54 million persons are having low vision, and 8 million are blind. ${ }^{1}$ The cause of both visual impairment and blindness is cataract, causing the blurring of normal lens which is transparent and crystalline in nature. ${ }^{2}$

On a large scale for eliminating avoidable blindness by the year 2020, World Health Organization (WHO) and the International Agency for the Prevention of Blindness (IAPB) in 1999 took a step towards VISION 2020 - The Right to Sight. ${ }^{3}$ Patients having mild grade of cataracts are prescribed glasses though in long period, it is managed by surgery. 4

The common surgery done for cataract is phacoemulsification surgery with the placement of a lens which is placed behind the iris.

The endothelium consists of a single layer of hexagonal cells which is vital for maintaining the transparency of the cornea. These cells do not replicate, and the loss is compensated by the migration, enlargement, and pleomorphism of the cells. ${ }^{5}$

The corneal dehydrated state is sustained by dynamic pumping action of $\mathrm{Na}+/ \mathrm{K}+-$ ATPase pump which drains excess fluid out of stroma through an active transport mechanism and barrier function. This guarantees its transparency.

There is a gradient across the corneal endothelium of bicarbonate ion. To maintain the pump activity, a minimal of $400-500$ cells $/ \mathrm{mm}^{2}$ is necessary. Failure of functioning of pump causes corneal decompensation and diminution of vision.

Endothelium do not have the ability to regenerate which causes the endothelium to become gradually decrease in number of cells. After any intraocular surgery or any ocular disease, the cell loss becomes worsened. ${ }^{6}$ During phacoemulsification surgery, ultrasonic energy is released which damages the cells and the cell junctions resulting in increased accumulation of fluid. Eventually loss of endothelial function can lead to corneal edema and decreased corneal transparency indicating pump function has been compromised.

The cells which are adjacent to them enlarge and migrate to maintain continuity or the cells, which is detected as increase in the coefficient of variation and reduction in the hexagonality of the endothelial cells. ${ }^{7}$ Pirazzoli et al. found that in phacoemulsification $16.67 \%$ endothelial cell loss occurs that was affected by various pre and intraoperative factors. ${ }^{8}$

Specular microscopy is a non-invasive technique that analyse the corneal layers under very high magnification. Modern specular microscope evaluate the size, shape and population of the endothelial cells.

There is a paucity of data from India on the effect of phacoemulsification on the corneal endothelium and central corneal thickness. Thus, the primary purpose of this study is to evaluate the postoperative changes in endothelial cell density and central corneal thickness (CCT) done by phacoemulsification technique.

\section{METHODS}

With due permission from scientific and ethical committee, patients with cataract presenting to the out-patient department of Acharya Vinobha Bhave Rural Hospital were selected for prospective observational study after taking the inclusion and exclusions criteria into consideration. Patients were counselled regarding the study and informed consents were obtained.

All data was collected by a single experienced ophthalmologist. The study period was of two years (September 2018 to September 2020).

The sample size was calculated using the following formula: Sample size formula with the desired error of margin-

$\mathrm{n}=\frac{\mathrm{Z}_{\alpha / 2}^{2} * \mathrm{P} *(1-\mathrm{P})}{\mathrm{d}^{2}}$

Where, $\mathrm{z} \alpha / 2$ - is the level of significance at $5 \%$ i.e. $95 \%$ confidence interval $=1.96$

By assuming the non-response rate, the rate being $10 \%$ i.e. 13 , we evaluated $107+13=$ minimum of 120 patients in the study. In this study, the sample size was of 120 patients.

\section{Inclusion Criteria}

- Patient's age: 45 - 80 years old.

- $\quad$ Senile cataract with nuclear sclerosis grade 2 according to Lens Opacities Classifaction System (LOCS) III classification.

\section{Exclusion Criteria}

- Patient not giving consent.

- $\quad \mathrm{H} /$ o diabetes mellitus.

- $\mathrm{H} / \mathrm{o}$ anti benign prostatic hyperplasia (BPH) medication.

- $\mathrm{H} / \mathrm{o}$ trauma to the cornea.

- H / o uveitis.

- Complicated cataract.

- Traumatic cataract.

- Number of endothelial cells less than $2000 / \mathrm{mm}^{2}$.

- Ocular diseases like glaucoma, corneal dystrophy, other corneal diseases.

- Mature senile cataract / hyper mature senile cataract / grade 1, 3, 4 nuclear sclerosis.

- Patient with intraoperative complications during cataract surgery.

- $\quad$ Pseudo exfoliation syndrome.

- Patients with the non-dilating pupil.

- Patients with shallow anterior chamber.

A detailed history of the patient and general vital data was taken. A comprehensive ophthalmic examination was performed on all participants, including visual acuity checked with Snellen's visual acuity chart and pinhole improvement was noted.

Thorough anterior segment examination was performed using a slit lamp for an anterior segment like cornea, anterior chamber, iris, pupil, lens. Cataract was graded according to LOCS III grading classification. Preoperative specular 
microscopy findings were noted. Patients underwent phacoemulsification technique.

Post-operative corneal thickness, endothelial cell density, endothelial cell loss, coefficient of variability, hexagonality was measured by noncontact specular microscope (Topcon SP 3000P) microscope at a resolution of $640 \times 480$ pixels and compared with the preoperative findings on 3 occasions -

- A day after surgery.

- Towards the end of 4th week after surgery.

- At the end of 12 th week after surgery.

\section{Statistical Analysis}

Statistical analysis was done by using descriptive and inferential statistics using Student's paired t test and software used in the analysis was SPSS 24.0 version and $\mathrm{P}<0.05$ is considered as the level of significance.

\section{RESULTS}

\begin{tabular}{|cccc|}
\hline Parameters & $\begin{array}{c}\text { No of Patients } \\
\text { (120) }\end{array}$ & $\begin{array}{c}\text { Percentage } \\
\text { (100) }\end{array}$ & Mean \pm SD \\
Age group (years) & & & $61.64 \pm 7.13$ \\
45 - 54 years & 19 & 15.83 & \\
55 - 64 years & 46 & 38.33 & \\
65 - 74 years & 51 & 42.50 & \\
$\geq 75$ years & 4 & 3.33 & \\
Gender & & 59.17 & \\
Male & 71 & 40.83 & \\
Female & 49 & 52.50 & \\
Laterality & 63 & 47.50 \\
\hline Right eye & 57 & Left eye \\
\multicolumn{2}{|c|}{ Table 1. Age Distribution, Gender Distribution, } \\
Laterality Distribution of the Patients \\
\hline
\end{tabular}

\section{Age}

In the present study of 120 patients, the minimum age of patients was 45 years and the maximum age was 77 years. Maximum patients were seen in the age group of 65 - 74 years i.e. 51 patients. The mean age was $61.64 \pm 7.13$.

\section{Gender}

Out of the 120 patients in this study, 71 patients $(59.17 \%)$ were male and 49 patients ( $40.83 \%$ ) were female.

\section{Laterality}

Out of 120 patients, 63 patients $(52.50 \%)$ had a cataract in the right eye while 57 patients $(47.50 \%)$ had a cataract in the left eye.

\begin{tabular}{|c|c|c|c|c|c|}
\hline $\begin{array}{l}\text { Specular } \\
\text { Microscopy }\end{array}$ & Mean & $\mathbf{N}$ & $\begin{array}{c}\text { Std. } \\
\text { Deviation }\end{array}$ & $\begin{array}{l}\text { Std. } \\
\text { Error } \\
\text { Mean }\end{array}$ & Percentage \\
\hline Preoperative & 2771.16 & 120 & 62.43 & 5.69 & - \\
\hline Postoperative day 1 & 2552.56 & 120 & 73.28 & 6.69 & $7.89 \%$ \\
\hline $4^{\text {th }}$ Week & 2456.90 & 120 & 70.58 & 6.44 & $11.34 \%$ \\
\hline $12^{\text {th }}$ Week & 2416.66 & 120 & 70.74 & 6.45 & $12.79 \%$ \\
\hline \multicolumn{6}{|c|}{$\begin{array}{l}\text { Table 2. Comparison of Endothelial Cell Density }\left(\mathrm{mm}^{2}\right) \text { at } \\
\text { Postoperative Day 1, } 4^{\text {th }} \text { Week and } 12^{\text {th }} \text { Week with Baseline }\end{array}$} \\
\hline
\end{tabular}

According to this study, mean endothelial cell density preoperatively was $2771.16 \pm 62.43$, on $1^{\text {st }}$ postoperative day it was reduced to $2552.56 \pm 73.28$, at end of 4 th week was $2456.90 \pm 70.58$ and at end of 12 th week was $2416.66 \pm 70.74$.

The P-value was 0.0001. By using Student paired t-test, endothelial cell density decreased significantly at day $1,4^{\text {th }}$ week and $12^{\text {th }}$ week compared with baseline.

\begin{tabular}{|cccccc|}
\hline $\begin{array}{c}\text { Specular } \\
\text { Microscopy }\end{array}$ & Mean & N & $\begin{array}{c}\text { Std. } \\
\text { Deviation }\end{array}$ & $\begin{array}{c}\text { Std. } \\
\text { Error } \\
\text { Mean }\end{array}$ & Percentage \\
Preop & 521.20 & 120 & 13.67 & 1.24 & - \\
Day 1 & 537.44 & 120 & 8.91 & 0.81 & $3.16 \%$ \\
$4^{\text {th }}$ week & 525.77 & 120 & 10.74 & 0.98 & $0.87 \%$ \\
12 $^{\text {th }}$ week & 523.68 & 120 & 11.30 & 1.03 & $0.47 \%$ \\
\hline Table 3. Comparison of Central Corneal Thickness $(\boldsymbol{\mu m})$ at Post- \\
Operative Day 1, 4 $^{\text {th }}$ Week and 12 ${ }^{\text {th }}$ Week with Baseline \\
\hline
\end{tabular}

In this study, mean central corneal thickness preoperatively was $521.20 \pm 13.67$, on $1^{\text {st }}$ postoperative day was $537.44 \pm 8.91$, at end of 4 th week was $525.77 \pm 10.74$ and at end of 12 th week was $523.68 \pm 11.30$.

The P-value was 0.000. By using Student paired t-test, the central corneal thickness increased significantly at postoperative day 1 as compared to baseline, then decreased at end of 4 th week and 12 th week but never came up to baseline.

\begin{tabular}{|cccccc|}
\hline $\begin{array}{c}\text { Specular } \\
\text { Microscopy }\end{array}$ & Mean & N & $\begin{array}{c}\text { Std. } \\
\text { Deviation }\end{array}$ & $\begin{array}{c}\text { Std. Error } \\
\text { Mean }\end{array}$ & $\%$ \\
Preop & 33.42 & 120 & 3.05 & 0.27 & - \\
Day 1 & 36.80 & 120 & 3.12 & 0.28 & $3.38 \%$ \\
$4^{\text {th }}$ week & 35.32 & 120 & 3.12 & 0.28 & $1.90 \%$ \\
12 $^{\text {th }}$ week & 34.51 & 120 & 3.10 & 0.28 & $1.09 \%$ \\
\hline Table 4. Comparison of the Coefficient of Variation (CV) (\%) at \\
Postoperative Day 1, 4 $^{\text {th }}$ Week and 12 ${ }^{\text {th }}$ Week with Baseline \\
\hline
\end{tabular}

According to this study, the mean of the coefficient of variation $(\mathrm{CV})$ preoperatively was $33.42 \pm 3.05$, on $1^{\text {st }}$ postoperative day was $36.80 \pm 3.12$, at end of 4 th week was $35.32 \pm 3.12$ and at end of 12 th week was $34.51 \pm 3.10$. The Pvalue was 0.0001 . By using Student paired t-test, there was a significant increase in the coefficient of variation at day 1 postoperatively as compared to baseline, then decrease at end of $4^{\text {th }}$ week and $12^{\text {th }}$ week but never came up to baseline.

\begin{tabular}{|c|c|c|c|c|c|}
\hline $\begin{array}{c}\text { Specular } \\
\text { Microscopy }\end{array}$ & Mean & $\mathbf{N}$ & $\begin{array}{c}\text { Std. } \\
\text { Deviation }\end{array}$ & $\begin{array}{c}\text { Std. } \\
\text { Error } \\
\text { Mean }\end{array}$ & Percentage \\
\hline Preop & 59.49 & 120 & 4.14 & 0.37 & - \\
\hline Day 1 & 55.84 & 120 & 4.17 & 0.38 & $3.65 \%$ \\
\hline $4^{\text {th }}$ week & 57.13 & 120 & 4.16 & 0.38 & $2.36 \%$ \\
\hline $12^{\text {th }}$ week & 57.95 & 120 & 4.14 & 0.37 & $1.54 \%$ \\
\hline \multicolumn{6}{|c|}{$\begin{array}{l}\text { Table 5. Comparison of Hexagonality }(\mathrm{HEX})(\%) \text { at } \\
\text { Postoperative Day 1, } 4^{\text {th }} \text { Week and } 12^{\text {th }} \text { Week with Baseline. }\end{array}$} \\
\hline
\end{tabular}

According to this study, the mean of hexagonality (HEX) preoperatively was $59.49 \pm 4.14$, on $1^{\text {st }}$ postoperative day was $55.84 \pm 4.17$, at end of $4^{\text {th }}$ week was $57.13 \pm 4.16$ and at end of $12^{\text {th }}$ week was $57.95 \pm 4.14$. The P-value was 0.0001 . By using Student paired t-test, there was a significant decrease in hexagonality at day 1 postoperatively compared to baseline, then slightly increased at $4^{\text {th }}$ week and $12^{\text {th }}$ week but never came up to baseline. 


\begin{tabular}{|cccccc|}
\hline $\begin{array}{c}\text { Specular } \\
\text { Microscopy }\end{array}$ & Mean & N & $\begin{array}{c}\text { Std. } \\
\text { Deviation }\end{array}$ & $\begin{array}{c}\text { Std. Error } \\
\text { Mean }\end{array}$ & Percentage \\
Day 1 & 218.60 & 120 & 60.86 & 5.55 & $7.89 \%$ \\
$4^{\text {th }}$ week & 314.26 & 120 & 58.01 & 1.67 & $11.34 \%$ \\
$12^{\text {th }}$ week & 354.50 & 120 & 58.48 & 0.86 & $12.79 \%$ \\
Table 6. Comparison of Endothelial Cell Loss (ECL) at \\
Postoperative Day 1, $4^{\text {th }}$ Week and 12 ${ }^{\text {th }}$ Week with Baseline. \\
\hline
\end{tabular}

In this study, the mean endothelial cell loss (ECL) on $1^{\text {st }}$ postoperative day was $218.60 \pm 60.86$ from the preoperative value, at the end of $4^{\text {th }}$ week postoperatively the cell loss was $314.26 \pm 58.01$ and at the end of $12^{\text {th }}$ week postoperatively, the cell loss was $354.50 \pm 58.48$.

The mean at the end of $4^{\text {th }}$ week from last follow up (postoperative day 1) was $95.66 \pm 18.31$ and the endothelial cell loss at the end of $12^{\text {th }}$ week from last follow up (at the end of $4^{\text {th }}$ week postoperative) was $40.23 \pm 9.48$. The P-value was 0.0001. By using the Student paired t-test, there was a significant endothelial cell loss from postoperative day 1 to postoperative $12^{\text {th }}$ week.

\section{DISCUSSION}

\section{Age}

The mean age in this study was $61.64 \pm 7.13$. Maximum patients were seen in the age group of 65 - 74 years i.e. 51 patients (Table 1). This was similar to a study conducted by Bamdad et al. where the mean age was $62.1 \pm 12.2 .{ }^{9}$ Similarly, in a study conducted by Sahu et al. the mean age was 64 years. $^{10}$

\section{Gender}

In our study, male preponderance (71 males) is seen over females (49 females) (Table 1). In a study conducted by Bamdad et al. on 85 patients, males were 42 and females were $43 .{ }^{9}$

\section{Endothelial Cell Density \\ Preoperative}

Preoperative mean endothelial cell density in our study was $2771.16 \pm 62.43$ (Table 2). In a study done by Bamdad et al. the mean preoperative endothelial cell density was $2791.15 \pm$ 99.86. ${ }^{9}$ The study conducted by Sahu et al. showed a mean preoperative endothelial cell density of 60 non-diabetic patients to be $2672.72 \pm 259.84 .{ }^{10} \mathrm{Wu}$ et al. conducted a study where mean preoperative endothelial cell density was $2743.10 \pm 58.03$, which was similar to our study. ${ }^{11}$ Similarly, the mean preoperative endothelial cell density calculated by Siddique et al. of 60 patients was $2745.35 \pm 395.27$. Wang et al. in his study of 60 non-diabetic patients found that the mean endothelial cell density calculated on a preoperative day was $2726.5 \pm 157.3 .^{12}$ Maggon et al. found out the mean endothelial cell density preoperatively as $2584.88 \pm 305.95 .{ }^{13} \mathrm{Li}$ in 2016 , done a study of 190 non-diabetic patients and found mean preoperative endothelial cell density to be $2867.53 \pm 277.51 .14$ Indra Dandaliya et al. in their study concluded that the preoperative mean endothelial cell density was $2393.93+$
251.92.15 As per the study of Simova et al. preoperative mean endothelial cell density was 2398 (1025 - 2965 cells / mm²).16

\section{Postoperative Day One}

On postoperative day one, our mean endothelial cell density was reduced to $2552.56 \pm 73.28$, which was significant as the P-value was 0.0001 (Table 2). Siddique et al. found that the mean endothelial cell density at postoperative day one of 60 patients was $2585.07 \pm 355.65$. Similarly, Wu et al. in their study concluded that the mean endothelial cell density of nondiabetic patients on postoperative day one was reduced to $2680.3 \pm 61.3$ and was significant. 11 These were correlating to our study. However, Bamdad et al. found that mean endothelial cell density on postoperative day one was reduced to 2472.87 \pm 472.14 and this result was significant. 9 This greater reduction of endothelial cells is probably due to higher surgery time and the inclusion of diabetic patients in their study.

\section{At the End of Postoperative 4th Week}

Endothelial cell density mean at the end of $4^{\text {th }}$ week in our study was $2456.90 \pm 70.58$, which was found to be significant having a P-value of 0.0001 (Table 2). Wu et al. found that the mean endothelial cell density at the end of the $4^{\text {th }}$ week was $2586.4 \pm 91.2$, was statistically significant. ${ }^{11}$ Wang et al. calculated mean endothelial cell density at the end of $4^{\text {th }}$ week around $2568.8 \pm 83.9 .12$ These findings were similar to our findings. However, Dandaliya et al. found mean endothelial cell density at $4^{\text {th }}$ week around $2145.08 \pm 279.76$, which was dissimilar from our study probably because they considered grade 3 cataract also. ${ }^{15}$

\section{At the End of Postoperative $12^{\text {th }}$ Week}

The mean endothelial cell density at the end of $12^{\text {th }}$ week postoperatively in our study was $2416.66 \pm 70.74$, which was significant with a P-value of 0.0001 (Table 2). Wu et al. found that mean endothelial cell density at postoperative $12^{\text {th }}$ week was $2569.3 \pm 79.5 .11 \mathrm{Li}$, calculated mean cell density at $12^{\text {th }}$ week postoperatively around $2463.17 \pm 268.5 .14$ These findings were similar to our studies.

\section{Central Corneal Thickness \\ Preoperative}

The preoperative mean in our study was $521.20 \pm 13.67$ (Table 3). According to a study conducted by Bamdad et al. on 85 patients, the mean preoperative central corneal thickness was $530.47 \pm 2.60^{9}$ and this was similar to our study. Budiman et al. calculated mean preoperative central corneal thickness as $511.9 \pm 31.5 .{ }^{17}$ According to Wang et al. the mean preoperative central corneal thickness of non- diabetics patients was $540 \pm$ 16.97.12 Maggon et al. found the mean preoperative central corneal thickness as $513.54 \pm 19.77 .{ }^{13}$ Hugod et al. in 2011, observed that mean preoperative central corneal thickness was $530 \pm 31.8 .18$ Morikubo et al. found that the mean preoperative central corneal thickness was $541.9 \pm 33.3 .{ }^{19}$ Zhao et al. calculated mean preoperative central corneal thickness as $542.62 \pm 43.11 .^{20}$ These findings were also comparable to our findings.

\section{Postoperative Day One}

We calculated the mean central corneal thickness on postoperative day one as $537.44 \pm 8.91$. There was an increment of $3.16 \%$ thickness as compared to the 
preoperative value (Table 3) Various studies were conducted. These are as follows -

\begin{tabular}{|c|c|c|c|c|}
\hline Sl. No. & Name & $\begin{array}{c}\text { Mean Central Corneal } \\
\text { Thickness on } \\
\text { Postoperative Day One } \\
\text { (Increase in Percentage as } \\
\text { Compared to Preoperative } \\
\text { Value) }\end{array}$ & $\begin{array}{c}\text { Similar } \\
\text { to } \\
\text { Our } \\
\text { Study }\end{array}$ & $\begin{array}{c}\text { Dis- } \\
\text { similar } \\
\text { to Our } \\
\text { Study }\end{array}$ \\
\hline 1. & Morikubo et al. & $563.25 \pm 33(3.94 \%)$ & - & - \\
\hline 2. & Maggon et al. & $525.42 \pm 20.09(2.14 \%)$ & - & - \\
\hline 3. & Dandaliya et al. & $543.46 \pm 47.64(8.19 \%)$ & - & - \\
\hline
\end{tabular}

Dandaliya et al.15 study was different from our study possibly because they have considered cataract till nuclear sclerosis grade 3 of LOCS III classification, and more dense cataract needs more energy which causes more endothelial cell loss thus, resulting in more corneal edema postoperatively, hence, there is further increase in central corneal thickness.

\section{At the End of $4^{\text {th }}$ Week Postoperatively}

We reported mean central corneal thickness as $525.77 \pm 10.74$. The central corneal thickness was increased by $0.87 \%$ as compared to the preoperative value and was decreased as compared to postoperative day one value (Table 3). Various other studies had results similar to those our study. Maggon et al. ${ }^{13}$ found that mean CCT on postoperative $4^{\text {th }}$ week was $515.78 \pm 19.9(0.04 \%)$ and similarly Morikubo et al. ${ }^{19}$ found that mean CCT on postoperative $4^{\text {th }}$ week was $542.1 \pm 33,(0.04$ $\%)$. These both were similar to our study.

\section{At the End of Postoperative $12^{\text {th }}$ Week}

We calculated postoperative $12^{\text {th }}$ week mean central corneal thickness as $523.68 \pm 11.30$, an increase of $0.47 \%$ in thickness as compared to the preoperative value (Table 3). Hugod et al. ${ }^{18}$ found the mean CCT on postoperative $12^{\text {th }}$ week as $529 \pm 34.3$, an increment of $0.13 \%$ and Wang et al. ${ }^{12}$ found the mean CCT on postoperative $12^{\text {th }}$ week as $547.7 \pm 9.8$, an increment of 0.87 $\%$. These findings were similar to our study.

\section{Coefficient of Variation \\ Preoperative}

In our study, the mean coefficient of variation preoperatively was $33.42 \pm 3.05$ (Table 4). According to Sahu et al. ${ }^{10}$ Budiman et al. ${ }^{17} \mathrm{Li}$ et al..$^{14}$ Dandaliya et al. ${ }^{15}$ Morikubo et al. ${ }^{19}$ Zhao et al. ${ }^{20}$ mean coefficient of variation preoperatively was $34.55 \pm 4.59$, $37.1 \pm 5.8,36.42 \pm 6.14,36.17 \pm 3.99,30.6 \pm 6.6,34.23 \pm 5.57$ respectively. These studies were correlating with our studies.

\section{Postoperative Day One}

We calculated the mean coefficient of variation at postoperative day one as $36.80 \pm 3.12$, an increment of $3.38 \%$ from the preoperative value (Table 4). According to Li et al. the mean coefficient of variation at postoperative day one of the non-diabetic patients was $38.94 \pm 5.97$, (increase of $2.52 \%$ ). ${ }^{14}$ Similarly, Morikubo et al. ${ }^{19}$ studies were found to be similar to our study. However Yang et al. studies and calculated the mean coefficient of variation at postoperative day one of the nondiabetic patients as $56.2 \pm 6.67$, which was about a $16 \%$ increase from preoperative value. ${ }^{21}$ This was dissimilar from our study. This is probably because they have considered age limit till 84 years.

\section{At the End of Postoperative $4^{\text {th }}$ Week}

We calculated the mean coefficient of variation at the end of the postoperative $4^{\text {th }}$ week as $35.32 \pm 3.12$, which is a $1.9 \%$ increase from preoperative value (Table 4). According to Zhao et al. the mean coefficient of variation on the postoperative $4^{\text {th }}$ week of non-diabetic patients was $37.62 \pm 5.78$, which was $3.39 \%$ increase from preoperative value. ${ }^{20}$ Similarly, Budiman et al. assessed changes in coefficient of variation on follow up of $4^{\text {th }}$ week postoperatively and found that there was an increase in the coefficient of variation, $38.1 \pm 7.5(1 \%$ increase). ${ }^{17}$ These studies were comparable with our studies. But Yang et al. found an increment of $11.2 \%$ from the preoperative value $(51.4 \pm 1.69)$, which deferred from our study. ${ }^{21}$

\section{At the End of Postoperative $12^{\text {th }}$ Week}

We calculated the mean coefficient of variation at the end of postoperative $12^{\text {th }}$ week and result was $34.51 \pm 3.10,1.09 \%$ increase as compared to preoperative findings. (Table 4) According to Zhao et al. ${ }^{20}$ the mean coefficient of variation at the end of the postoperative $12^{\text {th }}$ week of non-diabetic patients was $36.73 \pm 6.83$ (2.56\% increase). This increase in percentage was somewhat similar to our study. There was a difference in results when our study at postoperative $12^{\text {th }}$ week was compared to Yang et al. ${ }^{21}$ In their study, they calculated the mean coefficient of variation at $12^{\text {th }}$ week as 49 \pm 2.78 , which was $8.8 \%$ increase from their preoperative value. This is probably because they have considered the age limit till 84 years.

\section{Hexagonality \\ Preoperative}

In our study, the mean preoperative hexagonality was $59.49 \pm$ 4.14. (Table 5). According to Sahu et al. and Budiman et al. the mean preoperative hexagonality was $53.08 \pm 7.07$ and $52.1 \pm$ 10.6 respectively. ${ }^{10,17} \mathrm{~A}$ study conducted by Wu et al. the mean preoperative hexagonality was $58.41 \pm 13.27 .1^{11}$ Morikubo et al. calculated the mean preoperative hexagonality as $58.8 \pm$ 10.4.19 These two studies were found to be similar to our study. Zhao et al. Yang et al. calculated the mean preoperative hexagonality as $55.88 \pm 7.37$ and $55.30 \pm 3.68$ respectively. ${ }^{20,21}$

\section{Postoperative Day One}

We reported a decrease in mean hexagonality on postoperative day one and this was found to be $55.84 \pm 4.17$ which was roughly $3.65 \%$ decrease (Table 5) Morikubo et al. ${ }^{19}$ $\mathrm{Wu}$ et al. ${ }^{11}$ also found that there was a decrease in mean hexagonality and their findings were $56.7 \pm 10.4$ (2.1\%) and $54.24 \pm 13.28(4.17 \%)$ respectively, was comparable to our findings on postoperative day one. There was a difference in a study conducted by Yang et al. from our findings, as they reported a decrease in hexagonality by $7.3 \%{ }^{21}$ and we reported a decrease of $3.65 \%$. This difference in decrease might be because they have considered age up to 84 years in non-diabetic patients.

\section{At the End of Postoperative $4^{\text {th }}$ Week}

In our study, we calculated the mean hexagonality at the end of postoperative $4^{\text {th }}$ week as $57.13 \pm 4.16$, that is around 2.36 
$\%$ decrease from the preoperative value. (Table 5). Budiman et al. ${ }^{17}$ Morikubo et al. ${ }^{19}$ also reported mean hexagonality at the end of postoperative $4^{\text {th }}$ week had decreased as compared to preoperative value $[50.1 \pm 14.5(2 \%)$ and $57.2 \pm 10.4(1.6$ $\%)$ respectively]. Their findings were found to be similar to our findings though Yang et al. study was different from our study, $48.6 \pm 8.58(6.7 \%) .^{21}$

\section{At the End of Postoperative $12^{\text {th }}$ week}

Our mean hexagonality at the end of postoperative $12^{\text {th }}$ week was $57.95 \pm 4.14,1.54 \%$ decrease in hexagonality from the preoperative value (Table 5). According to the study conducted by Sahu et al. Wu et al. the mean hexagonality calculated at $12^{\text {th }}$ week after phacoemulsification surgery was $47.85 \pm 6.79$ ( $5.23 \%$ decrease), $56.91 \pm 15.28$ (1.5\% decrease) than preoperative value respectively. ${ }^{10,11}$ They were similar to our results.

\section{Endothelial Cell Loss \\ Postoperative Day One}

According to this study, the mean endothelial cell loss was $218.60 \pm 60.86$ cells $(7.89 \%$ ) (Table 6). According to Siddique et al. the mean endothelial cell loss on postoperative day one was $160.28 \pm 39.62$, that is $5.84 \%$. This was similar to our study. Li et al. reported the mean endothelial cell loss as 53.89, that is $1.88 \%{ }^{22}$ This was different from our findings.

\section{At the End of $4^{\text {th }}$ Week after Cataract Surgery}

We reported the mean endothelial cell loss at the end of postoperative $4^{\text {th }}$ week as $314.26 \pm 58.01(11.34 \%$ ) (Table 6$)$. According to Dandaliya et al. the mean loss of endothelial cells at postoperative $4^{\text {th }}$ week was $248.85+156.63(10.39 \%) .{ }^{15}$

\section{At the End of Postoperative $12^{\text {th }}$ Week}

We calculated the mean endothelial cell loss at the end of postoperative $12^{\text {th }}$ week as $354 \pm 58.48(12.79 \%$ ) (Table 6) Dandaliya et al. calculated the mean endothelial cell loss at postoperative $12^{\text {th }}$ week as $255.53+155.03(10.67 \%) .^{15}$ This was similar to our study.

\section{CONCLUSIONS}

Cataract extraction done by phacoemulsification surgery causes an alteration in endothelial cell density by reducing endothelial cell density postoperatively which was significant. The endothelial cell density is reduced after surgery and continues to get reduced until $3^{\text {rd }}$ month postoperatively. However, the reduction of cells is greater in $1^{\text {st }}$ postoperative day. Central corneal thickness increases significantly on postoperative day 1 . This is followed by a gradual decrease of central corneal thickness but never returning to the preoperative value which was also significant.

Corneal endothelial cells don't have the capacity to multiply and form new endothelial cells. To cover up the cell loss due to surgical trauma, the endothelial cells shape their morphology in terms of shape and size. After phacoemulsification surgery, there is an increment in the coefficient of variation of cells which is maximum in the early postoperative period. Gradually there is a decrease in the coefficient of variation as compared to postoperative day 1 , but the preoperative value is never reached. This change is statistically significant.

After phacoemulsification cataract surgery there is a decrease in the percentage of hexagonality of endothelial cells which occurs maximally in the $1^{\text {st }}$ postoperative day. Then it gradually approaches the preoperative value but never reaches the baseline value. This change was statistically significant.

Data sharing statement provided by the authors is available with the full text of this article at jemds.com.

Financial or other competing interests: None.

Disclosure forms provided by the authors are available with the full text of this article at jemds.com.

\section{REFERENCES}

[1] Pascolini D, Mariotti SP. Global estimates of visual impairment: 2010. Br J Ophthalmol 2012;96(5):614-18.

[2] Vijaya L, George R, Asokan R, et al. Prevalence and causes of low vision and blindness in an urban population: the Chennai glaucoma study. Indian J Ophthalmol 2014;62(4):477-81.

[3] World Health Organization. Vision 2020. WHO regional office for South-East Asia 2009.

[4] Dandona R, Dandona L. Refractive error blindness. Bulletin of the World Health Organization 2001;79(3):237-43.

[5] Werblin TP. Long-term endothelial cell loss following phacoemulsification: model for evaluating endothelial damage after intraocular surgery. Refract Corneal Surg 1993;9(1):29-35.

[6] Siddique MAS. Corneal endothelial change after phacoemulsification. Journal of Enam Medical College 2016;6(3):134-9.

[7] Ganekal S, Nagarajappa A. Comparison of morphological and functional endothelial cell changes after cataract surgery: phacoemulsification versus manual smallincision cataract surgery. Middle East Afr J Ophthalmol 2014;21(1):56-60.

[8] Pirazzoli G, D'Eliseo D, Ziosi M, et al. Effects of phacoemulsification time on the corneal endothelium using phacofracture and phaco chop techniques. J Cataract Refract Surg 1996;22(7):967-9.

[9] Bamdad S, Bolkheir A, Sedaghat MR, et al. Changes in corneal thickness and corneal endothelial cell density after phacoemulsification cataract surgery: a doubleblind randomized trial. Electron Physician 2018;10(4):6616-23.

[10] Sahu PK, Das GK, Agrawal S, et al. Comparative evaluation of corneal endothelium in patients with diabetes undergoing phacoemulsification. Middle East Afr J Ophthalmol 2017;24(2):74-80.

[11] Wu ZD, Zhong JX, Mai SL, et al. Influence of cataract phacoemulsification on corneal endothelial cells in diabetes. International Journal of Ophthalmology 2008;8:1908-9.

[12] Wang B, Li JX, Wang YL, et al. Clinical effect analysis of phacoemulsification on cataract patients with diabetes mellitus. International Eye Science 2013;13:1163-6. 
[13] Maggon R, Bhattacharjee R, Shankar S, et al. Comparative analysis of endothelial cell loss following phacoemulsification in pupils of different sizes. Indian J Ophthalmol 2017;65(12):1431-5.

[14] Li MH, Fu XL, Yang WF. Effect and risk factors for corneal endothelial cells after phacoemulsification in diabetic cataract patients. International Eye Science. 2016;16(6):1048-51.

[15] Dandaliya I, Bedi DK, Nainiwal SK. Evaluation of corneal endothelial cell changes in diabetic patients before and after phacoemulsification surgery: a comparative study. Indian Journal of Clinical and Experimental Ophthalmology 2018;4(4):458-64.

[16] Simova J, Radeva M, Grupchev D, et al. Central corneal thickness and morphological changes in the cornea after uneventful phacoemulsification. Bulgarian Review of Ophthalmology 2018;62(4):10-7.

[17] Budiman B. Comparison of endothelial cell density, morphological changes and central corneal thickness after phacoemulsification between diabetic and non- diabetic patients. The Open Ophthalmology Journal 2020;14(1):15-20.

[18] Hugod M, Storr-Paulsen A, Norregaard JC, et al. Corneal endothelial cell changes associated with cataract surgery in patients with type 2 diabetes mellitus. Cornea 2011;30(7):749-53.

[19] Morikubo S, Takamura Y, Kubo E, et al. Corneal changes after small-incision cataract surgery in patients with diabetes mellitus. Arch Ophthalmol 2004;122(7):966-9.

[20] Lin J, Zhao G. Changes of corneal endothelium in diabetes patients after cataract phacoemulsification surgery by confocal microscopy. Acta Ophthalmologica 2014;92(Special Issue 253).

[21] Yang $R$, Sha $X$, Zeng $M$, et al. The influence of phacoemulsification on corneal endothelial cells at varying blood glucose levels. Eye Sci 2011;26(2):91-5.

[22] Rao SK, Sen PR, Fogla R, et al. Corneal endothelial cell density and morphology in normal Indian eyes. Cornea 2000;19(6):820-3. 